\title{
WHEN CULTURE MEETS RELIGION: The Muludan Tradition in the Kanoman Sultanate, Cirebon, West Java
}

\author{
Mohamad Yusuf \\ Radbout University, Nijmegen, the Netherlands
}

\begin{abstract}
This article is based on a fundamental question, what is the relationship between practicing the Muludan tradition and seeking of power by the Royal family of the Kanoman Sultanate in Cirebon? The Muludan is a tradition conducted by the Royal family, and thousands of people participate in this tradition. This article is aimed to analyze the extent of which the Royal family uses Muludan tradition to regain their political power as they had in the past. Our participatory research shows that the Muludan tradition could be defined as a religious-cultural system. This is not only a religious ritual but also a cultural tradition. On the one hand this tradition is done primarily based on the knowledge, beliefs, norms and moral values of religious teachings. People participating in this tradition believe that they would gain God blessing (Ngalap Berkah) and Shafa'at as cited by the Quran and the Hadith. On the other hand, this tradition involves cultural tradition that has been practiced by the local people since long time ago. This research also found that the Royal family fails to use this tradition to gain political power as they intend to do. This tradition could mainly effectively be implemented in terms of the socio-cultural relationship between the Sultan and the followers. Political power, the Royal family aims to gain through conducting the Muludan tradition, does not significantly happen.
\end{abstract}

Key words: The Muludan Tradition, Power Relationship, Religious Identity, and the Kanoman Sultanate

\section{INTRODUCTION}

The celebration of the birth of the Prophet Muhammad in the Kanoman Sultanate in Cirebon, West Java is performed every year and is followed by thousands of people. It is a noble inheritance from which the Sultanate maintains and preserves this tradition up to the present. There are series of rituals carried out in the Kraton of Kanoman, begun on Safar $15^{\text {th.1 }}$. The peak

${ }^{1}$ Cirebonese people, similar with Javanese people use the moon calendar besides the sun calendar. Different with the sun calendar, the moon calendar is more difficult in determining new month or New Year because the revolving of moon is 29,5, thus in one month can be 29 days or 30 days. We, however, cannot determine which month is 29 days and which one is 30 days. 
of the Muludan tradition is so-called the ritual of Pelal ${ }^{2}$ or Panjang Jimat that is performed on Rabiul Awwal 12 $2^{\text {th }}$. Among the series of the rituals following the Muludan tradition, it also includes the performance of the Gamelan Sekaten or Gong Sekati started from Rabiul Awwal $7^{\text {th }}$ at $8 \mathrm{PM}$. This particular gamelan is inherited by the daughter of Sunan Gunung Jati (a Muslim missionary in this area d. 1521). He used this gamelan to spread Islam not only in Cirebon, but also in all areas in Java Island.

The tradition of celebrating the birth of the prophet Muhammad was initially introduced by Shalahuddin al-Ayyubi who governed Baghdad 700 years after the death of the Prophet Muhammad. The initial purpose of this celebration was to encourage his people to remember the life of the Prophet and to take good examples from what the Prophet Muhammad did during his life. The celebration did not only include reciting the life story and the good example of the Prophet Muhammad but also by reciting the Shalawat $\mathrm{Nabi}^{3}$ as a reflection of the love of the Prophet. This, furthermore, gained successful to strengthen the spirit of struggle against the Christian soldiers. This tradition then spread across the world, including to Cirebon. Sunan Gunung Jati and his uncle, who was also the son of Pangeran Cakrabuwana (the first governor of Cirebon), brought about this tradition to the people of Cirebon. Even though they perform similar ritual from what has been done by Shalahuddin Al-Ayyubi, but, as they also involve Hindu and Buddhist traditions makes this tradition differs from the one performed by Shalahuddin al-Ayyubi. ${ }^{4}$

As mentioned earlier, the peak of the Muludan tradition is the ritual of Pelal or Panjang Jimat. This ritual is the climax of the Muludan tradition. Literally, the word Panjang means "eternal" or "everlasting" (lestari). While Jimat means "something honorable". Therefore, Panjang Jimat literally means "something that has an everlasting honor". Contextually, Panjang refers to several long plates with the diameter of $50 \mathrm{~cm}$, and full of beautiful ornaments. The Panjang Ceramics belong to Pangeran Cakrabuwana, and he got these ceramics from a Buddhist Monk, Sang Hyang Bango. Pangeran Cakrabuwana received those ceramics on his way back from Padjajaran (150 Kms from Cirebon) to learn Islam. From this, we might see the influence of the Buddhist teachings in the Muludan tradition. The Jimat refers to rice boiled in a special way used special

${ }^{2}$ The word "Pelal" comes from Arabic word, "Iflal" means the peak of the something.

${ }^{3}$ The command on reciting the Shalawat is based on the Quranic text. Those who recite the Shalawat Nabi will get blessing from the Prophet. Innallaha wa malaikatahu yushalluna 'ala al-nabi, ya ayyuha alladzi na amanu shallu 'alaihi wa sallimu taslima (Q.S.33.56)

${ }^{4}$ According to RM. Arief Rahman, the Vice Secretary of the Family of Kanoman Sultanate Foundation (Yayasan Keluarga Kesultanan Kanoman), Cirebon has been known as the melting point of various religious beliefs and various ethnicities. The entity of Cirebon itself is the syncretization and the acculturation among them. 
flavors. This type of rice is believed to be a device of honoring the Prophet Muhammad. The rice is put in a long plate called Panjang Suku or Panjang Rasul, and supplemented with side dishes and nine plates of various fruits.

The Muludan tradition is obviously an attractive event for the people. The ritual, which lasts for one month and is performed once a year, was originally created to spread Islam by adapting local traditions. However, as time passed, this tradition is perceived as being used by the Royal family of the Kanoman Sultanate to regain their political power over the people in Cirebon. Our assumption is based on the fact that in the era of Sunan Gung Jati until the era of Pangeran Walangsungsang, the Cirebon Sultanate possessed strong political authority. Cirebon, at that time was the only powerful sultanate in West Java, particularly after the collapse of the Padjajaran and Galuh Kingdom.

According to Unang Suharjo, ${ }^{5}$ there are three phases when the political power of the Cirebon Sultanate decreased. Firstly was occurred after the Sunan Gunung Jati Era. After Sunan Gunung Jati died, Cirebon was governed by Panembahan Ratu Pakungwati I or Pangeran Zaenul Arifin. Cirebon's power at that time has significantly decreased because Cirebon did not have a powerful army, and thus the Mataram kingdom could easily conquer Cirebon. Since then, Cirebon became the colony of Mataram kingdom. Secondly, similar developments took place during the era of Dutch colonial. Even though Cirebon had no more political power, they were suspected by the Dutch to revolt against the colonial power. The Dutch administration divided Cirebon into three Sultanates: Kasepuhan, Kanoman and Kacirebonan Sultanate. Even though the division of the Cirebon into three Sultanates was presumably caused by internal conflicts among the three sons of Panembahan Girilaya, but the Dutch government took an active part in the process of dividing. Thirdly, it happened after the independence period. The new born of the Indonesian authority took over the political power of the Cirebon Sultanates, as also happen in other areas. Since then, the Cirebon Sultanates mainly possess cultural power.

Even though many Cirebonese people realize that the political power of the Sultanates in Cirebon ${ }^{6}$ is over, every tradition and ritual conducted by the Sultan attracts a lot of people. We might consider that the Sultan still possesses cultural and spiritual power. But, there might be an attempt of the Royal family of the Sultan to regain political power by using the Muludan tradition. The Royal family might refer to the history that their ancestor, Sunan Gunung Jati, not only possessed religious and cultural power, but also political power.

${ }^{5}$ See Unang Suharjo, Meninjau Sepintas Panggung Sejarah Pemerintahan Kerajaan Cerbon 1479 - 1809, Bandung: Tarsito, 1983.

${ }^{6}$ Cirebone has three big sultanates: Kasepuhan (the oldest and the biggest sultanate), Kanoman (the midst sultanate), and Kacirebonan (the youngest and the smallest sultanate). 
Therefore, it is obvious that the Muludan tradition that stands in continuity to the religious and cultural inheritance from Sunan Gunung Jati, is considered as an important instrument to regain political power of the Royal family of the Kanoman Sultanate. ${ }^{7}$

\section{THEORETICAL FRAMEWORK}

Everyone who tries to identify the ritual activity in Cirebon will face semantic difficulties when relating to meaning in language or relating to the connotations of words, because there is no proper comparison in the English language. In Cirebon, every ritual has its own name. The religious rituals that follow the tradition of the Muludan, could be understood as a ritual that contains of myth meaning because the reciting of Asyraqalan, ${ }^{8}$ Barzanji, and Shalawat $\mathrm{Nabi}$ are considered spiritual communications between those who believe and practice it and the Prophet Muhammad.

$\mathrm{O}^{\prime} \mathrm{Dea}^{9}$ explains that ritual is a ceremony that expresses deep feelings in terms of psychological and sub-consciousness feeling. Ritual has high emotional meaning, which is very complex and permanent. It also has functional meaning that is very important to certain people. The worship, giving honor and respect in religious terms, can be used to strengthen community solidarity. Another definition is found in Alexander's statement that traditional religious rituals open up ordinary life to ultimate reality or some transcendent being or force in order to tap its transformative power. ${ }^{10}$

A fundamental problem in defining ritual stems from the basic assumption that what the writer identify as ritual could be sometimes regarded as a crosscultural category with parallels elsewhere. There is no single type of activity called "ritual" that is instantly and universally recognizable, but there are certain forms of behavior that can be identified. S.J. Tambiah ${ }^{11}$ stated that the difference between ritual and non-ritual is relative rather than absolute and suggested the following working definition:

"Ritual is culturally constructed system of symbolic communication. It

${ }^{7}$ According to Ratu Raja Arimbi Nurtina, a sister and the spokeswoman of the Sultan of Kanoman, the Kraton should regain the political power from the people just like the era of Sunan Gunung Jati. She, furthermore explains that one of the ways to realize that condition is by regaining the trust of the people and shows that the existence of the Kanoman Sultanate by conducting ritual.

${ }^{8}$ Asyraqalan refers to the reciting of asyraqal badru 'alaina, the adoration to the Prophet Muhammad that is written by Ahmad Barzanji.

${ }^{9}$ O’Dea, Thomas, Sosiologi Agama. Jakarta: Rajawali, p. 77-78.

${ }^{10}$ Ibid, p. 139.

${ }^{11}$ Tambiah SJ. A Performative to Ritual. London: The British Academy and Oxford University Press. 
is constituted of patterned and ordered sequences of words and acts, often expressed in multiple media, whose content and arrangement are characterized in varying degree of formality (conventionality), stereotypy (rigidity), condensation (fusion), and redundancy (repetition)."

The idea of power of the Cirebonese society is hardly separated from their understanding of Islam. Using Anderson's idea of the concept of power in the Javanese society, for the Javanese conception differs from the concept of power that has evolved in the West since the middle Ages, including the views of the workings of politics and history: ${ }^{12}$

Clarification of the Javanese idea of power may be facilitated by schematic contrast with the more significant aspects of the modern European concept, which can be summarized under four main headings: Power is concrete; Power is homogeneous; The quantum of power in the universe is constant; and Power does not raise the question of legitimacy.

\section{THE PRACTICE OF THE MULUDAN TRADITION IN THE KANOMAN SULTANATE}

How is the Muludan tradition performed by the Kanoman Sultanate? The procession of the Muludan tradition that is routinely done in Kanoman Sultanate is begun on Rabiul Awwal $1^{\text {st }}$ or 12 days before the ritual of Panjang Jiamat as the peak ritual for the entire Muludan ritual in the Kanoman Sultanate. The tradition is begun with the ritual of making rice, which is called "the Nasi Jimat"13. The virgin women of the Keraton family make the Nasi Jimat. Firstly, they peel the rice one by one then they pound the rice very cautiously in order not to smash the rice. Then, the rice is boiled carefully. The rice after it is boiled is called Nasi Jimat. ${ }^{14}$ The uniqueness of this event is that the virgin women must do the process and their condition is not in menstruation.

After the making of the Nasi Jimat, the virgin women peel yellow sandalwood (Kayu Cendana) to make herbal cosmetic (Lulur), wax, sour fish, etc. All of these are part of ritual offerings (Sesaji) during the "Panjang Jimat" ritual. What is interesting from this process is that when they boil all these foods, they

${ }^{12}$ Anderson, Benedict R. O'G. The Idea of Power in Javanese Culture" in Culture and Politics in Indonesia, Claire Holt ed. Ithaca, New York: Cornell University Press. Pp. 21-22

${ }^{13}$ Jimat means si (ji) kang di ru (mat) or one thing that must be put up with, which means the Kalimat Shahadat. Thus, the festival of Panjang Jimat is a symbol of Muslim careness to put up with Kalimat Shahadat in their life. The Kalimat Shahadat, as I explained above symbolizes the key word to become Muslim. Therefore, the ritual of Panjang Jimat asserts the necessity of the Muslim to put up with Islam in entirely of life.

${ }^{14}$ According to some informants, rice is part of God blessing. Islam, furthermore, is descended through Muhammad as the Bless for entire world. The enthusiastic people to get the Nasi Jimat represent their enthusiastic to get berkah. 
must use the coconut oil that is used in the making of sesaji and the coconut must be picked from the coconut tree planted in the Pesantren Bendakerep. The next ritual is the butchering of buffalo. The meat of the buffalo is shared to the people and the head is put in the center of the Palace court (AlunAlun). All these processes: from the making of the Nasi Jimat until the ritual of butchering is undertaken from 1-7 Rabiul Awwal.

On Rabiul Awwal 7th at 9 AM, there is a ritual of heirlooms bath that is performed in the Mosque near by the Palace. Before the bathing ritual, the hairloms are processed from the Palace to the Mosque. During the procession, the people recite the Kalimat Shahadat and Shalawat Nabi. During the bath processes, there is also bathing of a set of the Gamelan Sekaten that will be used for a performance starting at 8 PM. During the process of the bath of Gamelan Sekaten, hundreds of people attempt to obtain the water from the bathing. They perceive that the water from the bathing of the Gamelan Sekaten and other heirloms will bring supernatural power (berkah). People use the water to water their plantation and to treat skin problems. ${ }^{15}$

The performance of the Gamelan Sekaten begins on 7 Rabiul Awwal around 8 PM. Prior to the performance, the Sultan of Kanoman, Sultan Raja Muhammad Emiruddin gives simbolic speech to open the performence, and gives authority to Lurah Nayaga to begin the Gamelan performance. As a means of spreading Islam in West Java, the Gamelan undoubtedly has historical meaning for Muslims. The gamelan is the symbol not only of the harmony between religious and local culture, but also the symbol of the struggle against the darkness. The last and the peak of ritual in the whole series of the Muludan tradition is the ritual of Panjang Jimat. This ritual is performed in Rabiul Awwal 12th started at $8 \mathrm{PM}$. The procession of the ritual of Panjang Jimat is attended by thousands of people from various places in Indonesia. Our observation found that some of the attendance come from obroad, such as Malaysia and Brunei Darussalam. The procession of the ritual of the Panjang Jimat has sacred meaning for the people. The procession symbolizes the birth of the Prophet Muhammad. The procession started from the Sultanate Palace to the Great Mosque around 300 meters. This procession consists of four stages before the baby is born. The four processes are symbolized by the so-called four to five Pancer (Papat kang kelima pancer/ the fourth stage and the fifth stage is the stage of baby is birth). The meaning of that symbol is the series of events of a person's birth from the breaking of the fetal membrane (Kakang Kekawah), the birth of the baby (Pancer), the stream of the blood from the mother (Adi Getih), the moving out of the placenta from the womb until the breaking of the navel (Tali Pusar). All

${ }^{15}$ Some other people even believe that by washing their face by that water, it will affect their face look younger. 
these stages are simbolized foods, sherbet of water, etc. ${ }^{16}$

Next, we would explain the symbol of the rows. The first row is the row of the Payung Keropak (the magnificence of umbrella that was made from the leaf of Palmyra), followed by the Penghulu of Keraton (the Sultanate officials that work for Sultan to conduct religious rituals in Kanoman Sultanate) and their staff. This row is the symbol of Abdul Muthallib (the grand father of the Prophet Muhammad) and Abu Thalib (the Uncle of the Prophet Muhammad). In the back of this row is the row of Bandrang Keraton (the row of the soldiers of the Kanoman Sultanate) who bring several traditional weapons, for instance: the Ekasula and the Catursula spear. In the third row is the row of people who bring the sacred of Tunggul Naga; one of the Cirebon sacred stuffs of the Kanoman Sultanate. It is a bound of the skin of the dragon, that according to the legend of the Cirebon Sultanate, is a follower of Panembahan Ratu, the grand son of Sunan Gunung Jati. The fourth row is the Chief Minister of Kanoman Sultanate (Patih), Pangeran Raja Muhammad Qodiran, who wear the golden long flowing robe and the turban with small crown on his head who represents the Sultan. That symbolizes the newborn baby of the Prophet Muhammad (symbolized by the golden robe), guarded by the elders and the relative of Kanoman Sultanate. During the ritual and while wearing the golden robe, the Patih is prohibited to speak a word.

The seventh row is the row of seven kinds of Tumpeng Jeneng that symbolize the seven days of the birth of human beings. The last row is the row of Nasi Jimat that consists of ten ceramics of Pangeran Cakrabuwana the place of Nasi Jimat and the fruits. The first ceramic and the Nasi Jimat symbolize the gift from the Sultan to the Prophet Muhammad. The other nine ceramics are used as the gift to the companions of the Prophet Muhammad or Khulafa alRasyidin, ${ }^{17}$ Syekh Abdul Qodir Jaelani, Sunan Gunung Jati, and the leader of Egypt Sultanate - the family of the father of Sunan Gunung Jati. While, the fruits symbolize the prosperous city as the dream city, that is put on a kind of plate, which is called the Dongdang.

The rows move from Bangsal Jinem, the place in which the Sultan usually receives the guests, to the Great Mosque. On the way from the Bangsal Jinem

${ }^{16} \mathrm{Abdullah}$, Irwan involves the sign and the signal, besides the symbol as the operator in the process of communication. All the three are the expressive action, at which, whether merely say something to the world order, or wants to change the order by metamorphosis. See Abdullah Irwan. Simbol, Makna dan Pandangan Hidup Orang Jawa Analisa Gunungan pada Upacara Grebeg. Yogyakarta: Balai Kajian Sejarah dan Nilai Tradisional. C.F. Edmund Leach in Culture and Communication, Cambridge University Press, 1976.

${ }^{17}$ There were four companions who were caliphates replaced the Prophet Muhammad to govern Arabs. There are: Abu Bakr shiddiq, Umar ibn Khattab, Utsman ibn 'Affan and 'Ali ibn Abi Thallib. 
to the Great Mosque, people recite the Shalawat Nabi. In the Great Mosque, they listen to the reciting of the history of the Prophet Muhammad from the Imam of the Mosque. Around 12 PM, the reciting of the history of the Prophet Muhammad finishes and the praying to Allah closes the ritual. All the charms are put in the mosque surrounding the seat of Pangeran Patih. In the end of the ritual, all the charms: Nasi Jimat, fruits, etc are shared with the people. Thousands of people in the mid night struggle to obtain part of the charms. They regard the charmes as having spiritual and supernatural power.

\section{THE MULUDAN TRADITION: A RELIGIOUS OR CULTURAL RITUAL?}

Having discussed the Muludan tradition, we would analyse this tradition particularly with regard to the idea of power existence. The Muludan tradition in the Kanoman Sultanate could be seen not only as a cultural system but also religious norms as this tradition consists of religious teachings and local culture. Many people consider that the Muludan tradition, which is held once a year in every Rabiul Awwal month in Kanoman Sultanate, is a manifestation of Islamic culture, because it contains a system of Islamic belief, knowledge and teachings. Learning a particular cultural system is very important in sociology and anthropology, in terms of people's social activity, which contains the meaning of cultural symbols, including Islamic symbols in the Muludan tradition.

As a cultural system, the Muludan tradition consists of the noble values of human life, especially the honor of the Prophet Muhammad. The Muludan tradition has the meaning of knowledge, because there involves knowledge transfer from across generations. ${ }^{18}$ People understand the meaning of the tradition from their ancestors and they take for granted the obligation to participate in this tradition. People are aware of the fact that the Muludan tradition is symbolized by reciting "Barzanzi", "Asyraqal", and so forth, as the manifestation of the respect and honor to the Prophet Muhammad. ${ }^{19}$

The Muludan tradition also involves cultural beliefs, because it consists of the belief of the coming of God's blessing to those who honor the birth of the

${ }^{18}$ From the conversations with some people who follow the Muludan tradition, I found that they come routinely and from various places such as Bandung, Jakarta, even from outside Java, like Medan, Padang, Lampung, etc. They come to the Muludan tradition, of course, for various reasons. Most of them, however, need to get berkah and shafaiat.

${ }^{19}$ According to Muhammad Rais, the Lurah of the Kanoman Sultanate, "Every Rabiul Awwal month, almost in every place in Indonesia, Muslims celebrate the birth of the Prophet Muhammad. They obviously can celebrate the birthday by various ways, such as sermon in the Mosque, etc. However, why they more likely to come to the Kanoman Sultanate than celebrate it in their own place?" Pak Rais convinces that the celebration of the Prophet Muhammad in the Kanoman Sultanate is not merely the celebration, but it has deep meaning for the people. 
Prophet Muhammad. ${ }^{20}$ In relation to the historical places that are considered sacred, or the ancient objects that are believed to have extra-natural powers, people believe that myth also has that kind of power. The Muludan tradition that is routinely conducted in the area of the Kraton provides the chance for people to bring their mystical wishes into reality. In relation with the perception above, Eliade ${ }^{21}$ with the concept of Hierophany, proposes the presence of the Ultimate reality in the ritual.

The Muludan tradition also has religious norms and values. People are integrated in the name of religious values and norms. Through the participation of the Muludan tradition, Muslims honor and respect each other, and society can remain unbreakable. Boisard ${ }^{22}$ describes how spiritual patterns are related to the worldly elements. In other words, the influence of religious norms and values that make up the Muludan tradition to the daily activities obviously represent the very basic understanding of Muslim to Islamic teachings. People believe that Islam invites its adherents to obey God's commands. The Quran teaches the norms and values to arrange the human relationship so that every Muslim as an individual and also as a collective, can ask other Muslims to do good deeds and prohibit the bad deeds. The application and the implementation of religious teaching create the transformation of every human being. As a religious and cultural tradition, the Muludan tradition appears as the active and dynamic expression of collective interest. ${ }^{23}$

The symbols that are used in the Muludan tradition, such as the reciting of Shalawat Nabi, Asyraqalan, dzikr, show the manifestation of Islamic culture that is crystallized in the Muludan tradition with the sub-system of knowledge, belief, and social cultural values that have been acknowledged by people. ${ }^{24}$ The reflection of culture, according to Ian Craib, ${ }^{25}$ obviously is an action or what people do on the basis of an idea or ideology that relates to a social system. Moreover, culture is a social world that relates to the idea of society, which contains norms and values.

${ }^{20}$ The Prophet said, "Those who honor my birth get shafa'at from me in the hereafter.

${ }^{21}$ Eliade, Mircea, The Sacred and the Profane, the Nature of Religion. New York: the Free Press Inc. p, 23

${ }^{22}$ Boisard, A. Marchel, Humanisme dalam Islam, Jakarta: Penerbit Bulan Bintang, 1980, p. 150.

${ }^{23}$ Islamic tradition has a concept emphasizing the need of collective behavior among its adherents to do in good deeds and refuse bad deeds, the so-called "Amr ma'ruf nahyi munkar".

${ }^{24}$ Even though some Muslim refuse to acknowledge the reciting of Barzanji is an Islamic tradition - because they only recognize the Islamic teachings are merely on what are written in the Quran and the Hadith, most Muslim as majority, however, regard the reciting of Shalawat and Barzanji are part of Islamic traditions.

${ }^{25}$ Craib, Ian, Modern Social Theory; from Parson to Habermas, Trans. Paul S. Baut, Jakarta: PT Grafindo Persada. 


\section{RITUAL AND POWER RELATION IN THE MULUDAN TRADITION}

How does the performance of the Muludan tradition represent the power relations? There was Emile Durkheim ${ }^{26}$ who introduced the concept of understanding society as an independent organic phenomenon. According to Durkheim, society has its own regulation, which develops to become a social norm. The entire methodology of Durkheim relates to the deterministic argument, explaining that every individual has no power over social boundaries, which are called collective solidarity; consensus or integration that produce the behavioral adaptation based on the social agreement of norms. Based on the solidarity concept as the implementation of social agreement, the relation among individuals must be developed on the basis of morality, religion, ideology and tradition that have been acknowledged by the society. ${ }^{27}$ Using the adhesion of the inter-relationship between religion on the one hand, and the tradition on the other hand implements a social solidarity system based on social consensus. What Durkheim proposes, is similar to what Ibn Khaldun's concept of Ashabiah. This concept is known as the concept of togetherness and brotherhood among the various different backgrounds of people. It, however, can be reached because of the similar interest of the people. People are bound by similar interest and goals of life. According to Ibn Khaldun, no single individual can live alone separate from other people. The ideal of collectivity, moreover, is the collectivity on the basis of religion and ritual. Religious ritual is a cohesive power that potentially creates strong social solidarity.

The Muludan tradition, as a religious and cultural tradition, effectively creates solidarity among many people. The involvement of thousands of people in this ritual, as the followers, proves that the Sultan has successfully bound the people into the collective consciousness either in the name of preserving the tradition or in the name of religious activity. In the name of preserving tradition, on the one hand, the Muludan is the continuation of the tradition that is performed by Sunan Gunung Jati. On the other hand, the Muludan tradition could also be regarded as a religious tradition because the reason that lies behind the tradition is to celebrate the birth of the Prophet Muhammad. People believe that by celebrating the birth of the Prophet Muhammad, they will not only get the blessing from God or shafa'at in the hereafter but also that it can bring the success in their live in the worldly life.

26 See Durkheim, Emile, the Rules of Sociological Method. Edited by George E.G. Catlin, New York: the Free Press, 1966

$27 \quad$ Ibid, p. 35. 
However, the collective solidarity from conducting the Muludan tradition could only effectively occur on the level of religious and traditional power. The Muludan tradition has succeeded in maintaining the spiritual and traditional power of the Sultan. Many people during the Muludan tradition come and visit the Sultan and ask for his blessing and hope to get shafaiat from God. Some of them bring Sega Tumpeng as the offering to the Sultan, and bottles of water to ask a prayer from the Sultan. They queue up patiently waiting for their turn to be able to see and kiss the arm of the Sultan. This phenomenon, however, merely occurs during the procession of the Muludan tradition in Rabiul Awwal month. Whereas in another time, the existence of the Sultan is almost forgotten by the people

The Muludan tradition has awakened the consciousness of the people to the existence of the Sultan as the descendent of Sunan Gunung Jati. People love the Sultan as apart of their obedience to Islamic law. The affection of people to the Sultan stems from the assessment that the Sultan is of the descent of Sunan Gunung Jati. Meanwhile, the affection of Sunan Gunung Jati is based on his descendent from the Prophet Muhammad. Whereas, the affection of the Prophet Muhammad is commanded by God. Thus, the affection of the Sultan is part of the affection of Sunan Gunung Jati. The affection of Sunan Gunung Jati is part of the affection of the Prophet Muhammad. The affection of the Prophet Muhammad is part of Islamic teaching.

According to Ratu Raja Arimbi Nurtina, a personal secretary of the Sultan, there are at least three reasons why the Sultan conducts the tradition of Muludan in Kanoman Sultanate:

1. As the manifestation of the affection to the Prophet Muhammad.

2. As the continuity and the preservation of the tradition that was introduced by the founding father of Cirebon, Sunan Gunung Jati.

3. As a medium to gather between the Sultan and the followers.

The three reasons above obviously have attracted people to come and follow the Muludan tradition. Thousands of people are involved during the procession rituals and they acknowledge that the Sultan is their leader, both as the religious leader, and as the tradition leader. The Sultan is acknowledged as the religious leader because he represents a person who masters in Islamic teachings, called Ulama. Meanwhile, as the traditional leader, the Sultan is acknowledged as the preserver of the tradition. People are obedient to follow all series of the Muludan tradition. People believe that their involvement in the Muludan could benefit to their life in the world and in the hereafter.

Historically speaking, the spread of Islam, especially in Java, implemented the socio-cultural model of the concept of a good relationship between Ulama and 
Umara, in other words, between religious leader and political leader. Sunan Gunung Jati was the model of the unity between these two characteristics. On the one hand, he was Ulama, a Panetep Panata Gama Rasul, and well known as an Islamic missionary; on the other hand, he had political authority as the leader of Caruban Empire. The unity of those two characteristic brought Sunan Gunung Jati as the ideal person in the history of Cirebon civilization. In the context of Cirebon at present, however, the position of Sultan Kanoman only has traditional power as the preserver of the tradition from his ancestors, as well as religious power as the Imam in the Mosque.

\section{CONCLUDING REMARKS}

Using Durheim analyses of social solidarity, the Muludan tradition could be seen as the adhesive of social solidarity, which aims to create integration not only between the Sultan and the followers, but also among the people. The Muludan as a religious and traditional ritual is the best way to create communication between the Sultan as the conductor, and the people as the practitioners. In addition to the concept of Javanese power that is proposed by Anderson is appropriately used in the context of Cirebon. People believe that the power is something concrete, homogeneous, and constant in total quantity, and without inherent moral implication. As Turner has observed that traditional religious rituals like the Muludan ritual open up ordinary life to ultimate reality or some transcendent being or force in order to tap its transformative power.

In the context of the Muludan tradition in the Kanoman Sultanate, however, those theories can be effectively implemented in terms of socio-cultural relationship between the Sultan and the people. The adhesive binding could mainly work in the level of traditional and religious domains. Whereas in the political aspect, the Muludan tradition, so far, had not any influence. However, the Muludan is successfully in awakening people consciousness of the existence of the Sultan as their leader. Comparing with the Kacirebonan Sultanate that does not conduct the same ritual, the Kanoman Sultanate has stronger religious and traditional power. However, the Kanoman Sultanate has less political power if it is compared with the Kasepuhan Sultanate because, the Kanoman Sultanate involved in internal political conflicts, thus the Cirebonese does not give political support in the General election. Based on the fact above, if the Sultan of Kanoman aims to gain both political and religious and traditional power over the people he must not only preserve the Muludan tradition, but also preserve a conducive condition internally among their internal stuff members 


\section{BIBLIOGRAPHY}

Abdullah, Irwan., 2002. Simbol, Makna dan Pandangan Hidup Orang Jawa Analisa Gunungan pada Upacara Grebeg. Yogyakarta: Balai Kajian Sejarah dan Nilai Tradisional.

Alexander, Bobby., 1987. Ritual and Current Studies of Ritual: Overview. In Stephen D. Galzier (ed.), Anthropology of Religion: a Handbook. Westport, CT: Greenwood Press.

Anderson, Benedict R. O'G., 1972. The Idea of Power in Javanese Culture, in Claire Holt, ed. 1972. Culture and Politics in Indonesia, Ithaca, New York: Cornell University Press.

, 1990. Language and Power: Exploring Political Cultures in Indonesia. Ithaca, NY: Cornell University.

Bell, Chaterin., 1997. Ritual Theory, Ritual Practice. Oxford and New York: Oxford University Press.

Craib, Ian., 1999. Modern Social Theory; from Parson to Habermas. Trans. Paul S. Baut, Jakarta: PT Grafindo Persada.

Dillistone FW., 2002. The Power of Symbol. Trans, Yogyakarta: Penerbit Kanisius.

De Graaf and Pigcaut., 1989. Kerajaan-Kerajaan Islam di Jawa: Peralihan dari Majapahit ke Mataram. Jakarta: Grafitti Press.

Durkheim, Emile., 1966. The Rules of Sociological Method. Edited by George E.G. Catlin, New York: the Free Press.

---------- ., 2001. the Elementary Forms of Religious Life. translated by Carol Cosman, New York: Oxford University Press.

Eliade, Mircea., 1990. The Sacred and the Profane, the Nature of Religion. New York: Basic Books Inc. Publisher.

Geertz, Clifford., 1975. Islam Observed. Chicago: the University of Chicago Press.

---.-., 1976. The Religion of Java. New York: The Free Press of Glencoe.

Kuntowijoyo., 2004. Raja, Priyayi dan Kawula. Yogyakarta: Ombak.

Schilbrack, Kevin (ed.)., 2004. Thinking Through Rituals Philosophical Perspectives. New York: Routledge.

Nasution, Harun., 1994. Islam ditinjau dari Berbagai Aspek. Jakarta: Universitas Indonesia Press.

O’Dea, Thomas., 1998. Sosiologi Agama. Trans, Jakarta: Rajawali.

Soenardjo, Unang., 1983. Meninjau Sepintas Panggung Sejarah Pemerintahan Kerajaan Cirebon 1479 - 1809. Bandung: Tarsito.

Tambiah SJ., 1979. A Performative to Ritual. London: The British Academy and Oxford University Press. 
